\title{
KÊTÊG
}

Jurnal Pengetahuan, Pemikiran dan Kajian Tentang Bunyi

Vol. 21., No. 2, November 2021, hal. 216-224

ISSN 1412-2065, eISSN 2714-6367

https://jurnal.isi-ska.ac.id/index.php/keteg

\section{GATI LAMBANGSIH LARAS SLENDRO PATHET MANYURA SEBAGAI KARYA INOVASI KARAWITAN GAYA YOGYAKARTA: KAJIAN MUSIKALITAS DAN KARAKTER GENDING}

\author{
Anon Suneko \\ ISI Yogyakarta, Jalan Parangtritis Km 6,5 \\ Sewon Bantul Yogyakarta Indonesia \\ anon.suneko@isi.ac.id \\ *Penulis Korespondens
}

\author{
Trustho \\ ISI Yogyakarta, Jalan Parangtritis Km 6,5 \\ Sewon Bantul Yogyakarta Indonesia \\ trustho@isi.ac.id
}

\author{
Salsa Bila \\ ISI Yogyakarta, Jalan Parangtritis Km 6,5 \\ Sewon Bantul Yogyakarta Indonesia \\ salsabila@gmail.com
}

dikirim 22 Februari 2022; diterima 25 Februari 2022; diterbitkan 01 Maret 2022

\begin{abstract}
Abstrak
Gati Lambangsih laras slendro pathet manyura merupakan salah satu gending gaya Yogyakarta yang diciptakan pada masa pemerintahan Sri Sultan Hamengku Buwono X. Kehadiran gending ciptaan baru berformat ladrang ini melengkapi estetika Beksan Bedaya Lambangsari yang digelar pada acara UyonUyon Hadiluhung pada tanggal 28 Desember 2020 di Kagungan Dalem Bangsal Srimanganti. Tidak seperti gending gati yang lain, Gati Lambangsih ini disajikan dengan gamelan berlaras slendro yang dikolaborasikan dengan alat musik tiup Barat brass section. Cita rasa baru gending Gati ini tentunya tidak bisa lepas dari motivasi dan konsep penciptaannya. Namun demikian, secara musikal, garap serta perpaduan gamelan dan brass section memerlukan kejelian dalam mencapai keselarasan sajian karawitan. Penelitian ini bertujuan untuk menelusuri aspek musikalitas serta pengaruh karakter atau watak gending sebagai implikasi penggunaan laras slendro dan brass section.
\end{abstract}

Kata Kunci : Gati Lambangsih, Bedaya Lambangsari, Gati Sléndro, Mentaraman

This work is licensed under a Creative Commons Attribution-ShareAlike 4.0

\begin{abstract}
Gati Lambangsih laras slendro pathet manyura is one of the Yogyakarta musical styles which was created during the reign of Sri Sultan Hamengku Buwono X. This new creation in the ladrang format complements Beksan Bedaya's aesthetic Lambangsari, which was held at the Uyon-Uyon Hadiluhung event on December 28, 2020, at Kagungan Dalem Ward Srimanganti. Unlike other gending Gati, Gati This symbol is presented with a slendrobarreled gamelan in collaboration with brass section western wind music. Of course, the new taste of Gending Gati cannot be separated from the motivation and concept of its creation. However, musically, working and blending Gamelan and brass sections require carefulness in achieving harmony in the musical presentation.
\end{abstract}

Keyword: Gati Lambangsih, Bedaya Lambangsari, Gati Sléndro, Mentaraman

\section{Pendahuluan}

Karawitan gaya Yogyakarta (Mataraman/ Metaraman) sebagai salah satu gaya dalam karawitan Jawa telah ada dan berkembang sejak Pemerintahan Sri Sultan Hamengkubuwono I. Karaton Kasultanan Ngayogyakarta Hadiningrat secara turun-temurun mewariskan gagrag Ngayogyakarta dari generasi ke generasi. Spirit patriotik dan militeristik yang dimiliki juga mampu 
memberikan identitas budaya yang khas. (Suharti and St 2012, 83). Ciri fisik dalam karawitan gaya Yogyakarta dapat dikenali melalui bentuk intrumen, sedangkan ciri yang bersifat musikal dapat dikenali melalui: susunan balungan gending, garap gending, laya atau tempo, irama, pola tabuhan ricikan, dan sebagainya. (Sugimin 2018,68) Gaya Yogyakarta sejak awal kemunculannya hingga saat ini telah mengalami beberapa fase perkembangan. Perkembangan gagrak Yogyakarta gagrak Mataraman, terjadi seiring dengan bergulirnya zaman dan semakin majunya peradaban masyarakat pendukungnya, sehingga kemutakhiran cara pandang dan pola pikir yang maju mempengaruhi perkembangan daya cipta, rasa dan karsa. (Hastanto 1997) Dalam ikatan cultural basic yang cukup kuat, segala bentuk perkembangan yang terjadi di dunia seni karawitan gaya Yogyakarta baik secara langsung maupun tidak langsung semakin memperkuat identitas kultur yang khas dari corak seni karawitan tradisi Yogyakarta.

Karawitan gaya Yogyakarta dapat menjalankan perannya sebagai seni sajian mandiri maupun pengiring seni pertunjukan lain. Sajian mandiri yang khas dari gaya ini adalah garap soran (Sugimin 2006) yang berupa sajian instrumentalia yang ditabuh dengan "sora" atau keras dengan nuansa musikal agung, gagah, wibawa, mrabu, ngratoni (- et al. 2014). Dalam fungsinya sebagai pendukung seni pertunjukan lain, kehadiran karawitan selalu erat berkaitan dengan beberapa presentasi seni pertunjukan seperti wayang, ketoprak dan tari (Trustho 2005). Dalam perannya sebagai pengiring seni pertunjukan lain, gamelan memiliki peranan vital dalam mendukung kelangsungan presentasi estetik seni yang diiringinya. Keduanya terlibat tarik-ulur dalam sebuah proses dinamisasi yang saling mengisi dalam orientasi keselarasan sajian karya seni yang estetis.(Rahayu 2018) Keduanya saling mempengaruhi sehingga substansi-substansi yang bersinggungan secara langsung dapat mempererat konektivitas estetik sajian karya seni. Beberapa repertoar klasik istana kasultanan Yogyakarta antara lain bedhaya, srimpi, wayang wong, beksan pethilan, serta beberapa tarian lepas baik putra maupun putri telah menunjukkan betapa intimnya hubungan karawitan dengan seni tari. Keduanya saling mendukung dalam kerangka dan struktur yang menyesuaikan kebutuhan estetika sajian karya seni. Sinkronisasi substansi-substansi karawitan terhadap pemenuhan kebutuhan aksentuasi, karakter, ritme maupun suasana, memberikan keleluasaan terhadap ruang gerak para kreator seni istana pada masa itu. Penyesuaian pada beberapa aspek musikal karawitan menurut kebutuhan pertunjukan tari menimbulkan konsekuensi pada spesifikasi standar karawitan sehingga terjadi pergeseran, perubahan, penemuan garap baru karawitan dalam konteks iringan tari.(Syaiful 2013)

Dalam sebuah catatan penting (Pemut Amemutra Pranatan Ungeling Kagungan Dalem Gangsa Sekati, 1 Kanjeng Kyai Gunturmadu, 2 Kanjeng Kyai Nagawilaga, 1952 : 1-98) pada masa Sultan Hamengku Buwono VIII, terdapat 63 gending untuk sekatenan. Dari enam puluh tiga gending yang ditulis, enam belas gending di antaranya adalah gending khusus untuk sekaten. Setiap gending ditulis lengkap dengan racikan (kalimat lagu yang dipergunakan untuk mengawali gending sekaten sebelum penyajian gending pokok). Selebihnya adalah gending-gending mares atau gending gati. (Subuh 2016, 179). Sebanyak 47 gending gati yang tercipta sampai masa pemerintahan Sri Sultan HB VIII semuanya berlaras pelog. Maka tidak heran jika masyarakat karawitan meyakini penggunaan laras pelog sebagai salah satu ciri dari gending gati karena tidak ada satupun gending gati yang berlaras slendro. Penyajian gending gati yang khas dengan perpaduan gamelan, snare dan instrument brass menciptakan nuansa agung yang semakin mendukung suasana dan karakter tari Bedaya yang diiringinya. 
Gati Lambangsih laras slendro pathet manyura merupakan salah satu gending gaya Yogyakarta yang diciptakan pada masa pemerintahan Sri Sultan Hamengku Buwono X. Kehadiran gending ciptaan baru berformat ladrang ini melengkapi estetika Beksan Bedaya Lambangsari yang digelar pada acara Uyon-Uyon Hadiluhung pada tanggal 28 Desember 2020 di Kagungan Dalem Bangsal Srimanganti. Bedaya Lambangsari menggunakan gending Lambangsari laras slendro pathet manyura sebagai iringan pokoknya. Sesuai tradisi yang berlaku, gending beksa bedayan laras slendro akan menggunakan gending ladrang berlaras slendro dalam irama 2 sebagai pengiring kapang-kapang maju dan kapang-kapang mundur. Pergelaran acara Uyon-Uyon Hadiluhung pada tanggal 28 Desember 2020 menghadirkan gati Lambangsih laras slendro pathet manyura sebagai pengiring kapang-kapang maju dan kapang-kapang mundur menggantikan gending ladrang. Tidak seperti gending gati yang lain, Gati Lambangsih ini disajikan dengan gamelan berlaras slendro yang dikolaborasikan dengan alat musik tiup Barat brass section dengan susunan garap pecahan suara yang lebih kompleks. Cita rasa baru gending Gati ini tentunya tidak bisa lepas dari motivasi dan konsep penciptaannya. Namun demikian, secara musikal, garap serta perpaduan gamelan dan brass section memerlukan kejelian dalam mencapai keselarasan sajian karawitan. Nuansa dan karakter yang terbentuk dari sajian gending gati Lambangsih laras slendro pathet manyura secara langsung mempengaruhi suasana dan karakter sajian beksan bedaya Lambangsari. Laras slendro yang berkarakter tegas, maskulin, lugu, berpadu dengan nuansa tari bedaya yang agung, halus, serta mrabu(Benamou 1998).

Berpijak dari paparan diatas, maka kajian musikalitas dan karakteristik gending Gati Lambangsih ini merupakan hal menarik untuk diteliti. Melalui penelitian ini maka akan dapat ditelusuri mengenai aspek musikalitas, termasuk didalamnya adalah persoalan garap baik lagu, wirama maupun rasa gendingnya. Selain itu penelitian ini juga akan mengungkapkan dampak penggunaan pathet slendro sebagai media tutur musikal terhadap karakteristik gending yang secara lebih jauh dapat mempengaruhi estetika sajian Bedaya Lambangsari.

\section{Metode}

Fenomena hadirnya Gati Lambangsih dalam perkembangan karawitan dari dalam lingkungan kraton Kasultanan Yogyakarta ini akan dijelaskan melalui metode deskriptif analitik secara detail melalui pengumpulan data-data dipandu landasan teori yang relevan, sehingga relevansi antara garap musikalitas dengan karakteristik gending dapat diteliti secara objektif. Sifat kualitatif dalam penelitian ini adalah untuk memaparkan adanya inovasi musikal melalui penelusuran berdasarkan data-data yang otentik sekaligus menguji seberapa jauh musikalitas dan karakteristik gending gati Lambangsih laras slendro pathet manyura mampu mendukung presentasi beksan Bedaya Lambangsari.

\section{1) Lokasi Penelitian}

Lokasi penelitian merupakan suatu tempat atau wilayah dimana penelitian tersebut akan dilakukan. Penelitian tentang aspek musikalitas dan karakteristik gending gati Lambangsih laras slendro pathet manyura akan dilaksanakan di Yogyakarta atas beberapa pertimbangan bahwa Keraton Kasultanan Yogyakarta merupakan tempat dimana gending gati Lambangsih laras slendro pathet manyura diciptakan. Sumber informasi mengenai latar belakang dan konsep penciptaan akan dapat diperoleh melalui observasi dan pengumpulan data di K.H.P. Kridhamardawa sebagai bagian urusan seni budaya di Keraton Kasultanan Ngayogyakarta Hadiningrat. Dipilihnya lokasi 
ini merupakan suatu keleluasaan dalam mengumpulkan data, referensi dan melakukan observasi tentang pergeseran karakteristik gending pengiring kapang-kapang maju-mundur dalam beksan Bedaya Lambangsari sejak munculnya gending Gati Lambangsih laras slendro pathet manyura.

\section{2) Subjek Penelitian}

Subjek penelitian atau responden adalah orang yang diminta untuk memberikan keterangan tentang suatu fakta atau pendapat. Sebagaimana dijelaskan oleh Arikunto bahwa subjek penelitian adalah subjek yang dituju untuk diteliti oleh peneliti. Jadi, subjek penelitian itu merupakan sumber informasi yang digali untuk mengungkap fakta-fakta di lapangan (Suharsimi 2006). Subjek penelitian ditentukan berdasarkan orang yang dianggap paling tahu tentang informasi yang dibutuhkan dalam penelitian, sehingga akan memudahkan peneliti dalam menelusuri situasi yang diteliti. Peneliti menentukan subjek penelitian berdasarkan permasalahan yang akan diteliti tentang kajian musikalitas dan karakter gending gati Lambangsih laras slendro pathet manyura. Maka, subjek penelitiannya adalah gending gati Lambangsih laras slendro pathet manyura dari konsep, proses dan implementasinya dalam konteks iringan tari bedaya Lambangsari.

\section{3) Jenis dan Sumber Data}

Pengumpulan data dilakukan melalui studi pustaka dan wawancara kepada narasumber. Studi pustaka dilakukan oleh peneliti di perpustakaan ISI Yogyakarta, UGM, dan Perpustakaan Pusat Daerah Istimewa Yogyakarta serta perpustakaan pribadi peneliti. Studi pustaka dilakukan untuk mencari referensi, mencari ke-orisinalitas-an, serta dalam rangka mencari teori yang relevan dengan topik penelitian ini. Langkah lain yang dilakukan peneliti adalah wawancara terhadap narasumber. Pemilihan narasumber dilakukan dengan berdasarkan pada relevansi kompetensi bidang dan profesionalitasnya terhadap substansi penelitian. Informan yang dipilih adalah informan yang diakui dalam bidang penciptaan gending klasik di Yogyakarta baik yang berkecimpung secara langsung maupun memiliki pengalaman mengenai seluk beluk perkembangan karawitan di Yogyakarta. Beberapa narasumber yang dipilih oleh peneliti di antaranya: M.W. Sumanto Susilo Madyo, salah satu abdi dalem Punokawan K.H.P. Kridhamardawa yang dianggap memiliki pengalaman secara langsung dalam seluk-beluk penciptaan gending Gati Lambangsih laras slendro pathet manyura. Narasumber kedua adalah R.M. Surtihadi, seorang akademisi Jurusan Musik Fakultas Seni Pertunjukan ISI Yogyakarta, arranger musik dan pakar abdi dalem Keraton Kasultanan Ngayogyakarta Hadiningrat, yang dianggap memiliki banyak informasi mengenai teori-teori dan aplikasi musik barat dalam gamelan khususnya gending gati atau mares.

Langkah berikutnya adalah pendokumentasian data lapangan dengan perangkat rekam audio visual portable serta pengumpulan sumber referensi audio maupun audio visual (kaset, CD, VCD, atau DVD) yang berkaitan dengan objek penelitian. Setelah data terkumpul, lalu disusun, dipilih dan selanjutnya diolah sedemikian rupa sehingga data rekam audio visual ini nantinya melengkapi sekaligus membantu penulis di dalam melakukan penelitian ini secara objektif. Fakta di lapangan dideskripsikan secara objektif dengan pendekatan emik yakni mengungkap hasil penelitian berdasarkan narasumber pokok di lapangan.

\section{4) Teknik Pengumpulan Data}

Teknik pengumpulan data penelitian didapat dari hasil observasi, wawancara, serta dokumentasi(Satori 2007). 


\section{5) Teknik Analisis Data}

Data lapangan yang telah diperoleh selanjutnya dianalisis untuk kepentingan penelitian. Analisis data dilakukan terhadap data hasil wawancara dan dokumen audio maupun audio visual. Analisis data harus dilakukan secara teliti dan cermat apalagi jika ditemukan ketidakjujuran dari pembicaraan yang disampaikan oleh narasumber.

Tahapan berikutnya adalah penyusunan laporan penelitian.

\section{1) Langkah-Langkah Penelitian}

Langkah-langkah yang dilalui dalam penelitian ini meliputi; Pemilihan tema, topik dan judul penelitian, Identifikasi kebutuhan objektif (latar belakang) penelitian, Identifikasi, pemilihan dan perumusan masalah, Studi Pustaka/Telaah Teori, Perumusan hipotesis, Identifikasi variabel dan data penelitian, Pemilihan alat pengumpul data, Perancangan pengolahan data, Penentuan sampling, Pengumpulan data, Pengolahan dan analisis data, Penarikan kesimpulan, Penyusunan laporan penelitian .

\section{Pembahasan}

\section{A. Struktur Penyajian dan garap ricikan gamelan Gending Gati Lambangsih laras slendro pathet manyura}

Penyajian gending Gati Lambangsih dari bagian buka dilanjutkan ke bagian dados hingga suwuk dijalankan secara mat sebagai salah satu ciri pembawaan gending Metaraman. Gending gati memiliki ciri-ciri spesifik yang membedakannya dengan gending-gending lainnya, bahkan dengan gending yang sama-sama berbentuk ladrang. Menurut Subuh dalam Tugas Akhirnya yang berjudul "Gending- Gending Mars atau Gati Kraton Yogyakarta" menjelaskan tentang ciri-ciri atau kekhususan yang dimiliki oleh gending gati diantaranya adalah sebagai berikut: dalam penyajiannya dibuka dengan kalimat lagu satu gongan, tidak seperti ladrang-ladrang yang lainnya, dalam penyajiannya gending gati selalu disajikan dalam irama I (tanggung), gending gati atau mars termasuk gending soran, kendhangan dalam gending gati menggunakan kendhangan khusus yaitu kendhangan sabrangan, gending gati berlaraskan pelog (Kurniawan and others 2018). Ricikan bonang barung sebagai pamurba lagu dalam penyajian Gati Lambangsih menjalankan fungsinya secara konvensional. Bonang barung sebagai ricikan pambuka bertugas mengawali sajian dengan memainkan satu cengkok balungan bagian pertama sebagaimana buka gending Gati pada umumnya. Garap kendang kalih pada gending Gati Lambangsih laras slendro pathet manyura menggunakan pola kendangan yang berbeda dengan pola kendang sabrangan pada gendinggending Gati yang pernah ada sebelumnya.(Bambang Sri Atmojo 2011)

\section{B. Orientasi garap instrumen brass dalam sajian Gending Gati Lambangsih laras slendro pathet manyura.}

Penyajian gending Gati pada umumnya menggunakan gamelan Jawa yang dipadukan bersamaan dengan instrumen musik Barat, pada musik tiup seperti terompet, trombon, klarinet dan pada gesek ada contra bas gesek, celo, biola alto dan violin serta pada perkusi ada tambur (snare drum) (Kurniawan and others 2018). Konsep perpaduan gamelan berlaras pelog dan instrument barat merupakan salah satu tradisi khas dalam musik istana Kasultanan Ngayogyakarta Hadiningrat sejak era pemerintahan Sri Sultan Hamengku Buwono VIII yang terus dilestarikan 
hingga saat ini. Kemiripan pola interval nada diatonis dan laras pelog semakin menipiskan perbedaan disiplin dua sistem nada yang sesungguhnya berbeda dan sulit disatukan. Perpaduan laras pelog dan instrument barat kian lazim baik dalam kehidupan karawitan istana maupun luar tembok istana, atau denga kata lain menjadi "mainstream" sebagai bentuk akulturasi budaya.(Jayantoro 2018). Menurut Joko Suprayitno, Gati Lambangsih menjadi tantangan dan permasalahan tersendiri dalam penyusunan aransemen musik brass-nya, karena disamping ini merupakan hal yang baru, pemakaian laras slendro pada gamelan memerlukan kecermatan dan kehati-hatian karena perbedaan pola jarak nada diantara dua system nada. Kekhawatiran yang dialami oleh arranger instrument brass pada awalnya adalah kemiripan pembawaan laras slendro yang dimainkan menggunakan instrument barat akan condong ke nuansa musik cina sehingga akan menjauhkan rasa "jawa" pada sajian Gati Lambangsih dan ini menjadi hal yang paling dihindari. Melalui beberapa proses pengamatan dan Analisa laras slendro pada gamelan di Keraton, arranger menggunakan urutan nada pada brass do, re, fa, sol, la , bukan do, re, mi, sol, la, do seperti pada umumnya. Ini dimaksudkan untuk mengurangi ketidaksesuaian perpaduan laras slendro dan tangga nada diatonic.

$\begin{array}{lllll}1 & 2 & 3 & 5 & 6 \\ \mathrm{Ji} & \text { Ro } & \mathrm{Lu} & \mathrm{Ma} & \mathrm{Nem} \\ \mathrm{Fa} & \text { Sol } & \mathrm{La} & \mathrm{Do} & \mathrm{Re}\end{array}$

Menurut Joko Suprayitno, karena gending Gati atau mares secara konvensional berspirit tegas seperti lagu mars dalam musik barat, maka olah garap harmoninya akan lebih mengacu pada spirit musik mars. Hal ini merupakan salah satu strategi lain untuk meminimalisir nuansa musik cina, dan akan lebih menguatkan roh laras slendro gamelan jawa. Instrumen trombon memuliki keleluasaan dalam menyamankan dan menyelaraskan nada dengan laras gamelan slendro meskipun dengan disiplin musik barat. Untuk memperkaya harmoni dalam musikalitas Gati Lambangsih, arranger menggunakan acuan perpaduan dua nada gembyang dan kempyung dan menghindari perpaduan 3 nada untuk menjaga keutuhan bunyi laras slendro jawa yang khas. Konsep nada seleh pada laras slendro pathet manyura menurut Marto Pangrawit adalah bahwa nada seleh utama atau dong terletah pada nada nem(Martopangrawit 1972). Secara detail, nada seleh yang lain dalam laras slendro pathet manyura adalah sebagai berikut :

\begin{tabular}{|r|c|c|c|c|}
\hline Dong & Ding & Kempyung Atas & Kempyung Bawah & Pelengkap \\
\hline 6 & 5 & 3 & 2 & 1 \\
\hline
\end{tabular}

\section{Inovasi musikal dalam sajian Gending Gati Lambangsih laras slendro pathet manyura}

Gending gati Lambangsih merupakan salah satu wujud inovasi gending iringan tari istana pada era pemerintahan Sri Sultan Hamengkubuwana X. Sesuai dengan hasil pengamatan penulis terdapat dua unsur kebaruan yang diekperimentasikan dalam Gati Lambangsih yaitu kebaruan pada elemen lagu atau melodi dan kebaruan pada garap elemen ritme yang terletak pada pola permainan kendang. 
Lagu balungan yang berpijak pada orientasi keruntutan melodi atau lagu sesuai dengan basic seleh nada pada laras slendro pathet manyura. Unsur kebaruan pada instrument ritmis dapat ditemukan pada variasi pola kendangan yang digunakan pada penyajian Gati Lambangsih. Jika pada umumnya, gending berbentuk Gati menggunakan kendangan Sabrangan saja, maka Gati Lambangsih ini menggunakan pola kendang khusus atau pamijen yang mengadopsi pola kendang yang digunakan pada musik keprajuritan di Kasultana Ngayogyakarta Hadiningrat (Rintoko 2016). Hal tersebut menjadi salah satu strategi kreatifitas yang muncul yang berpijak pada idiom-idom bunyi yang sudah ada (Munandar 1999).

\section{Karakteristik Gending Gati Lambangsih laras slendro pathet Manyura.}

Gending Gati pada umumnya merepresentasikan nuansa gagah, agung, mrabu, berwibawa melalui sajian gending berstruktur ladrang, berlaras pelog, dan khas dengan adanya kolaborasi gamelan dan instrumen tiup barat dalam setiap sajiannya. Nuansa patriotik yang megah menempatkan fungsi dan peranan penting gending Gati sebagai gending pengiring keluar dan masuknya penari bedaya, khususnya pada bedaya yang diiringi dengan gending berlaras pelog. Perpaduan suara gamelan garap soran dengan instrumen brass, tambur/snare drum, dan bedug menguatkan nuansa keagungan dan mempertegas langkah pada gerakan kapang-kapang bedhayan. Hingga saat ini, keberadaan gending Gati dan tari bedaya saling melengkapi dan melekat satu sama lain memperkuat ciri khas karya seni istana Yogyakarta.

Sebagai sebuah gending Gati berlaras Slendro, maka karakteristik gending Gati Lambangsih tidak dapat lepas dari karakter mendasar laras slendro pada gamelan. Slendro terdiri dari 5 nada yang ber-jangkah relatif sama.(Supanggah 2002) Struktur interval nada pada laras slendro memunculkan karakter maskulin, lugu, tegas.(Suneko 2017)

Diciptakannya gending Gati Lambangsih sebagai bagian dari gending beksan Bedaya Lambangsari memiliki tujuan normatif untuk mendukung presentasi estetis tari bedaya itu sendiri. Optimalisasi pencapaian karakter dan suasana sajian tarian telah dilakukan dengan desain laras gending yang memiliki kemampuan dalam memperkuat nuansa patriotik yang tegas sesuai dengan konsep yang telah dikemukakan oleh K.P.H. Notonegoro selaku Penghageng K.H.P. Kridha Mardowo yang sekaligus pemrakarsa penciptaan gending Gati Lambangsih laras slendro pathet manyura sebagai gending pengiring kapang-kapang bedaya Lambang Sari yang berlaras slendro.

Pasca penyajian perdana gending Gati Lambangsih di Keraton Kasultanan Yogyakarta penulis melakukan interview beberapa pengamat karawitan dan tari. Beberapa pengamat berpendapat bahwa gending Gati yang berlaras slendro kurang merepresentasikan keagungan beksan bedaya. Pemakaian laras slendro pada gending Gati dianggap aneh, karena menurut para pengamat, laras slendro slendro lebih dekat dan cocok untuk membawakan suasana maupun karakter yang lugu, suasana pedesaan, kerakyatan, kesederhanaan atau prasaja. Bahkan menurut informasi yang didapatkan dari beberapa penari maupun guru tari Keraton, pada waktu awal mendengarkan gending Gati berlaras slendro, mereka merasa aneh, janggal, karena suasana dan karakter yang dimunculkan dari gending pengiring kapang-kapang bedhayan terasa sangat jauh dari yang mereka bayangkan seperti pada gending Gati atau mares berlaras pelog. Suara tiupan brass yang mendampingi permainan gamelan berlaras slendro pada awalnya terkesan mengganggu suasana keagungan sajian tari bedaya. Namun seiring dengan proses penyesuaian dan pembiasaan dalam beberapa kali Latihan atau gladhen, maka akhirnya para penari mulai nyaman dan terbiasa dengan hal baru tersebut. Dengan berpijak pada motivasi penciptaan gending yang berorientasi 
pada penguatan atau penegasan nuansa patriotik dan keprajuritan, maka gending Gati Lambangsih secara sinergis dan perlahan membuktikan dukungannya terhadap penguatan karakter pada presentasi estetik tari bedaya Lambangsari dengan cara yang berbeda dari kebiasaan sebelumnya.

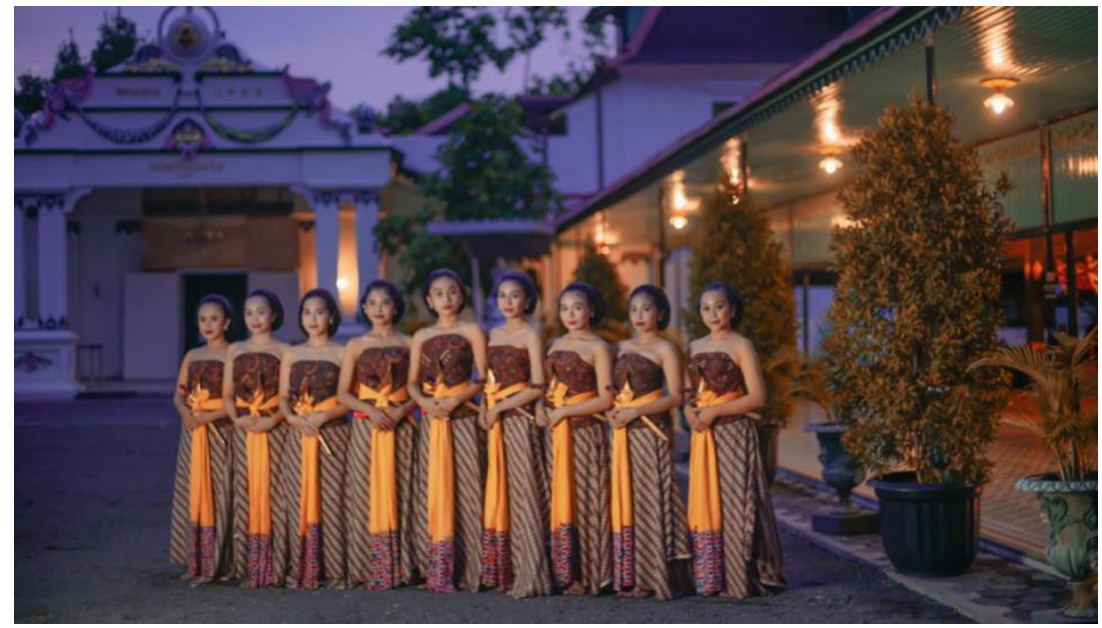

Gambar 1. Bedhaya Lambangsari dalam busana gladhen

(Sumber: https://www.kratonjogja.id/tak-benda/tari/46/bedhaya-lambangsari)

\section{Kesimpulan}

Gati Lambangsih merupakan gending yang diciptakan pada masa pemerintahan Sri Sultan Hamengkubuwono X. Gending ini disajikan untuk mengiringi kapang-kapang kondur/mundur pada kagungan Dalem Beksan Bedhaya Lambangsari yang dipergelarkan pada acara Selasa Wagen di Bangsal Kasatrian Keraton Kasultanan Yogyakarta.

Sebagai salah satu inovasi dalam gending beksan bedhayan, didalamnya terdapat beberapa unsur kebaruan antara lain; penggunaan laras slendro pada penyajian gending Gati, garap instrument barat (brass) yang berpijak pada konsep perpaduan nada gembyang dan kempyung yang diabstraksi oleh variasi lagu brass yang tidak selalu sama dengan lagu balungan gending, dan penggunaan kendangan keprajuritan.

Inovasi musikal ini mengusung spirit patriotik sebagai jiwa dari seni budaya gaya Mataraman yang menggunakan laras slendro pada gamelan sebagai penguat karakteristik yang gagah dan tegas.

\section{Daftar Pustaka}

Raharja, Timbul Haryono, R.M. Soedarsono, and Adhi Susanto. 2014. "Pengaruh Sri Sultan Hamengku Buwono I Pada Seni Karawitan Kraton Yogyakarta." Resital: Jurnal Seni Pertunjukan. https:// doi.org/10.24821/resital.v15i1.799.

Bambang Sri Atmojo. 2011. Laporan Penelitian Kendhangan Pamijen Gending Gaya Yogyakarta. Yogyakarta: Lembaga Penelitian Institut Seni Indonesia Yogyakarta.

Benamou, Marc Laurent. 1998. Rasa in Javanese Musical Aesthetics. University of Michigan.

Hastanto, Sri. 1997. "Pendidikan Karawitan: Situasi, Problema, Dan Angan-Angan Wujudnya." Dalam Wiled, Jurnal Seni, II.

Jayantoro, Setyawan. 2018. “TRANSFORMASI KONFRONTATIF KOMPOSISI GAMELAN BARU: Revitalisasi Penciptaan Inovatif Dan Peran Vital Perguruan Tinggi Seni." Kêtêg: Jurnal 
Pengetahuan, Pemikiran Dan Kajian Tentang Bunyi 18 (1): 25-38.

Kurniawan, Diky, and others. 2018. "Musik Tiup Barat (Brass Band) Dalam Sajian Gending Gati." Institut Seni Indonesia Yogyakarta.

Martopangrawit, L R. 1972. Pengetahuan-Karawitan. Aski.

Munandar, Sukarni Catur Utami. 1999. Kreativitas Dan Keberbakatan: Strategi Mewujudkan Potensi Kreatif Dan Bakat. Gramedia Pustaka Utama.

Rahayu, Rini. 2018. "Karawitan Tari Topeng Sekartaji Tunggal." Keteg: Jurnal Pengetahuan, Pemikiran Dan Kajian Tentang Bunyi 18 (November): 90-107.

Rintoko, Arsa. 2016. “Akulturasi Dalam Gending Keprajuritan Keraton Yogyakarta." Institut Seni Indonesia Yogyakarta.

Satori, Djam'an. 2007. “Metode Penelitian Kualitatif (Mata Kuliah Analisis Penelitian Kualitatif)." Bandung: Sekolah Pascasarjana UPI.

Subuh, Subuh. 2016. “Garap Gending Sekaten Keraton Yogyakarta." Resital: Jurnal Seni Pertunjukan. https://doi.org/10.24821/ resital.v17i3.2227.

Sugimin, Sugimin. 2006. "GENDING SORAN DALAM KARAWITAN GAYA YOGYAKARTA." Keteg: Jurnal Pengetahuan, Pemikiran Dan Kajian Tentang Bunyi 6 (2).

- - - 2018. “Mengenal Karawitan Gaya Yogyakarta." Keteg: Jurnal Pengetahuan, Pemikiran Dan Kajian Tentang Bunyi 18 (2): 67-89.

Suharsimi, Arikunto. 2006. "Prosedur Penelitian Suatu Pendekatan Praktik." Jakarta: Rineka Cipta, $120-23$.

Suharti, Theresia, and S St. 2012. "Bedhaya Semang Karaton Ngayogyakarta Hadiningrat Reaktualisasi Sebuah Tari Pusaka." Universitas Gadjah Mada.

Suneko, Anon. 2017. "Pyang Pyung: Sebuah Komposisi Karawitan." Resital: Jurnal Seni Pertunjukan. https://doi.org/10.24821/resital.v17i1.1690.

Supanggah, Rahayu. 2002. Bothekan Karawitan. Masyarakat Pertunjukan Indonesia.

Syaiful, Sagala. 2013. “Konsep Dan Makna Pembelajaran Untuk Membantu Memecahkan Problematika Belajar Dan Mengajar." Bandung: Alfabeta.

Trustho. 2005. Kendang Dalam Tradisi Tari Jawa. surakarta: STSI Press.

\section{Diskografi}

\section{https://youtu.be/hkSGElBw61A}

